\title{
Reality vs. Perception
}

\section{Charlene O'Hanlon, ACM Queue}

0 ctober is upon us, the month that celebrates the struggle between perception and reality. Every October 31, children of all ages don costumes and masks in pursuit of receiving treats or playing tricks, trying desperately to fool everyone into thinking they're a witch or a goblin or a clown instead of a 10-year-old girl or a teenage boy or a middle-aged business executive.

I, for one, would rather celebrate reality. Don't get me wrong-I love Halloween and the joy it brings to all recipients of candy (myself included, since I always buy too much). But one of the most hazardous elements of life is perception, and often what is reality and what is perceived as reality are two dangerously different things.

I should have taken Latin in high school, because as I deal more and more with the issue of reality vs. perception I often find myself muttering a few of those wellknown phrases that mean so much in certain situations. Most days, thankfully, it's more carpe diem than mea culpa. But in my quest to expand my multisyllabic arsenal, I've discovered a plethora of Latin phrases that fit well into my average days, including (in alphabetical order):

- ad absurdum (to the point of absurdity)

- ad hominem (appealing to feelings rather than reason)

- advocatus diaboli (devil's advocate)

- de gustibus non est disputandum (there is no accounting for taste)

- dum spiro, spero (as long as I breathe, I hope)

- in vino veritas (in wine there is truth)

- velle est posse (where there is a will, there is a way) Judging from the popularity of some of the more common Latin phrases, I think our founding fathers of language had a lot of insight into the human condition and its associated ethos and egos. In dealing with the issue of reality vs. perception, however, sometimes insight isn't enough.

Anyone who has ever tried to balance a checkbook will tell you numbers can lie. Anyone who has been misunderstood in an e-mail will tell you that people will read what they want to read, not necessarily what you've written. And anyone who has been unfairly accused of an action will tell you that the accusation stings.

Still, no matter what the situation, one thing always

\author{
Cleaning up \\ MISPERCEPTION \\ (OR BAD CODE) \\ IS A MESSY TASK.
}

rings true: Cleaning up

after an unintended

misperception can be

downright messy-much

like cleaning up bad code

that was created to keep an outdated legacy system running years after it should have been retired. Unfortunately, in most enterprise environments, that scenario is more a reality than a perception.

This month's issue deals specifically with that reality. How can a company plan ahead to enable its systems to grow old gracefully and be able to avert disaster when the processor starts smoking? How can it adjust its current operations to accommodate future advances in system technology? And when it comes to accommodating the advances, how fast is too fast? How slow is too slow?

John Mashey tackles the last set of questions and the (some might argue) disastrous results in his article, "The Long Road to 64 Bits." While the beauty of 64-bit architecture was too great to ignore, the constraints of implementing such a system on an epic scale proved to be a debacle for numerous companies, not the least of which were the chip makers, who lost revenue hand over fist, and the developers, who were building for a market that did not exist on a scale large enough. "Past decisions have unanticipated side effects that last decades and can be difficult to undo," Mashey writes.

Other articles in this month's issue deal with perceptions also, but on different scales. Damon Poole, founder and CTO of AccuRev, in his article, "Breaking the Major Release Habit," looks at the potentially time-saving method of agile development. Although the process can help developers save precious time (and save companies from the vicious cycle of major release patches), whether it can deliver on its promises in today's complex software development environment remains to be seen.

This month's issue is ripe with perception. The reality will make itself known soon enough. When it does, just follow the empty candy wrappers to find me. $Q$

CHARLENE O'HANLON can't be held responsible for what is said under the influence of too much sugar. 